\title{
Effects of Gender on Teachers' Perceptions of School Environment, Teaching Efficacy, Stress and Job Satisfaction
}

\author{
Van Dat Tran ${ }^{1}$ \\ ${ }^{1}$ Research and International Relations Office, An Giang University, Vietnam \\ Correspondance: Van Dat Tran, Research and International Relations Office, An Giang University, Vietnam. Tel: \\ 84-76-256-565 (1714). E-mail: tvdat@agu.edu.vn
}

Received: August 31, 2015

Accepted: September 23, 2015

Online Published: September 25, 2015

doi:10.5430/ijhe.v4n4p147

URL: http://dx.doi.org/10.5430/ijhe.v4n4p147

\begin{abstract}
This study investigates how teachers' perceptions of school environment factors, teaching efficacy, teacher stress and job satisfaction, and to determine whether gender was a differentiating factor. A total of 387 Vietnamese junior high school teachers completed one questionnaire for four sections about school-level environment, teaching efficacy, teacher stress, and job satisfaction. The results reveal that most of these teachers had high perceptions of school-level environment factors (principal leadership, mission consensus, professional interest, affiliation, student support, innovation, resource adequacy), teaching efficacy (classroom management, student engagement, and instructional strategies), job satisfaction, and teacher stress (classroom stress and workload stress). Results also show that statistically significant differences were found between females and males on the mean scores of school-level environment factors, teaching efficacy, stress, and job satisfaction. Female teachers scored higher than male teachers on both stress while male teachers scored higher than female teachers on school-level environment factors, teaching efficacy and job satisfaction. Male teachers with less stress had higher perceptions of school-level environment factors, higher teaching efficacy and higher job satisfaction, whereas female teachers with greater stress had lower perceptions of school-level environment factors, lower teaching efficacy and lower job satisfaction. Educational implications of the findings are discussed.
\end{abstract}

Keywords: Gender differences, Teacher perceptions, School-level environment, Teaching efficacy, Teacher stress, Job satisfaction

\section{Introduction}

The strength of an effective school always depends on all aspects of school-level environment (Collie, Shapka, \& Perry, 2012). In recent decades, four areas of research focused on teachers' perceptions of school environment, teaching efficacy, teacher stress, and job satisfaction have received more attention among researchers and policy makers (Shann, 1998; Tschannen-Moran \& Hoy, 2007; Wilson, 2002). The research results have shown that school environment, teaching efficacy, teacher stress, and job satisfaction not only affect teachers in terms of motivation, engagement, and commitment to teaching, but also affect students in terms of learning responsibility and academic performance (Schaufeli \& Bakker, 2004; Chen, 2007; Weiss, 1999). The findings of several studies show that students' greater academic achievement and aspirations are encouraged when teachers have lower perceived stress and greater perceived teaching efficacy and job satisfaction (Caprara, Barbaranelli, Steca, \& Malone, 2006; Ross, Hogaboam-Gray, \& Hannay, 2001). A powerful association between aspects of school-level environment and teachers' outcomes such as teaching efficacy, teacher stress, and job satisfaction has been found in recent research studies (Collie et al., 2012; Fisher \& Fraser, 1990). In addition, school-level environment has the relationships with professional and organizational commitment (Tarter, Hoy, \& Kottkamp, 1990), teacher retention (Miller, Brownell, \& Smith, 1999). Apparently, a positive school environment results in an increase in teaching efficacy and teachers' job satisfaction (Taylor \& Tashakkori, 2010), and a decrease in stress included student behavior stress and workload stress (Collie et al., 2012). Some international research studies indicate that school-level environment factors have been considered as key predictors of teachers' teaching competencies, stress and job satisfaction (Butt et al., 2005). However, in the setting of Vietnamese junior high schools, the teachers' perceptions of school-level environment, teaching competencies, teacher stress, and job satisfaction are rarely investigated. The purpose of this study is, therefore, to examine how teachers' perceptions of school environment factors, teaching efficacy, teacher stress and job satisfaction, and to determine whether gender was a differentiating factor. The present study may provide 
Vietnamese school leaders with potentially additional information in improving school-level environment to increase teachers' sense of efficacy and job satisfaction, and minimize their stress at work.

\subsection{School-level environment}

School-level environment is used to refer as "the atmosphere, culture, resources, and social networks of a school" (Loukas \& Murphy, 2007, p.293). In a systematically review of previous research studies on school-level environment, Cohen, McCabe, Michelli, and Pickeral (2009) established four aspects of school school-level environment. They are physical and social-emotional safety, quality of teaching and learning between individuals at a school, relationships and collaboration, and the structural environment (Cohen et al., 2009). These four aspects of school-level environment affect the experiences of individuals within that organization (Cohen et al., 2009). The findings of previous research showed that teachers' perceptions of school environment have been found to be associated with their sense of stress (E. Skaalvik \& S. Skaalvik, 2009), teaching efficacy (Hoy \& Woolfolk, 1993), job satisfaction (Butt et al., 2005; Taylor \& Tashakkori, 1995), teachers' burnout (Grayson \& Alvarez, 2008) and their work commitment (Collie, Shapka, \& Perry, 2011). The present study, based on the four factors of school-level environment established by Cohen et al., (2009), identified seven factors of school-level environment, included student support (refers to a good relationship between teachers and students, and student behavior), affiliation (refers to assistance, advice and encouragement of colleagues), professional interest (refers to professional matters, work interest, and professional development), mission consensus (refers to staff consensus, and school goals), innovation (refers to planned change and experimentation), resource adequacy (refers to facilities, finance, equipment and resources), and principal leadership (refers to the ability of management and leadership), and investigates how teachers' perceptions of school environment factors, and to determine whether gender was a differentiating factor.

\subsection{Teaching efficacy}

Teachers' teaching efficacy refers to teachers' beliefs about their capabilities in carrying out a particular task successfully (Bandura, 1977). In the classroom, teaching efficacy has been defined as a teacher's "judgment of his or her capabilities to bring about desired outcomes of student engagement and learning, even among those students who may be difficult or unmotivated" (Tschannen-Moran \& Hoy, 2001, p.783). Teaching efficacy has been associated with efficacy for student engagement, efficacy for classroom management, and efficacy for instructional strategies (Klassen \& Chiu, 2010; Hoy \& Spero, 2005; Tsouloupas, Carson, Matthews, Grawitch, \& Barber, 2010; Tschannen-Moran \& Hoy, 2001). Efficacy for student engagement refers to teachers' ability to promote student motivation in learning, efficacy for classroom management refers to teachers' ability to control disruptive behavior and have students follow classroom rules, and efficacy for instructional strategies refers to teachers' ability to use effective strategies for teaching (Tschannen-Moran \& Hoy, 2001). The sense of teaching efficacy construct has been linked with important outcomes for teachers, including the use of effective teaching efficacy (Klassen \& Chiu, 2010; Hoy \& Spero, 2005), better classroom management (Tsouloupas et al., 2010), and greater teacher well-being (Tschannen-Moran \& Hoy, 2001). Teachers' sense of teaching efficacy has the relationship with school-level environment factors (Collie et al., 2012; Taylor \& Tashakkori, 2010). Particularly, the greater sense of school-level environment factors has been associated with important outcomes for teachers, including the greater use of effective teaching strategies (Klassen \& Chiu, 2010; Hoy \& Spero, 2005), better classroom management strategies (Tsouloupas et al., 2010), and greater student engagement in learning (Tschannen-Moran \& Hoy, 2001). In this study, three factors of teachers' teaching efficacy, which included efficacy for student engagement, efficacy for classroom management, and efficacy for instructional strategies were identified to investigate how teachers' perceptions of teaching efficacy, and to determine whether gender was a differentiating factor.

\subsection{Teacher stress}

In comparison with other jobs, teaching is considered as a very stressful job (Chaplain, 2008; De Nobile \& McCormick, 2005; Kyriacou, 2001). Teachers' work stress reflects the experience of unpleasant emotions as a result of teaching work (Kyriacou, 2001). The profession of teaching may result in personal satisfaction but it also results in stress (Schwarzer \& Hallum, 2008). Teachers' work stress not only come from the demands of administrators, colleagues, students, and parents but also comes from work overload, student misbehavior, level of conflict with students and colleagues, and a lack of recognition for accomplishments (Greenglass \& Burke, 2003). Some research studies indicated that up to one third of teachers are stressed or extremely stressed (Geving, 2007; Thomas, Clark, \& Lavery, 2003). Although there are many causes of teaching stress, two types of stress - stress related to students' behavior and discipline, and stress related to workload, have been investigated (Boyle, Borg, Falzon, \& Baglioni Jr., 1995). Many research studies show that these two types of stress are associated with several negative outcomes for teachers, such as increased burnout, reduced sense of teaching efficacy, reduced job satisfaction, and reduced 
teaching commitment (Boyle et al., 1995; Jepson \& Forrest, 2006; Kyriacou, 2001; McCarthy, Lambert, O’Donnell, \& Melendres, 2009; Klassen \& Chiu, 2010; Klassen \& Chiu, 2011). In addition, teachers with greater teacher stress have lower self-efficacy (Schwarzer \& Hallum, 2008; Skaalvik, 2007), poorer teacher-pupil relationship, and lower levels of effectiveness (Kokkinos, 2007; Kyriacou, 2001). In the present study, two types of teachers' stress - stress related to students' behavior and discipline, and stress related to workload were identified to examine how teachers' perceptions of stress and job satisfaction, and to determine whether gender was a differentiating factor..

\subsection{Job satisfaction}

Job satisfaction refers to the degree to which teachers' job-related needs such as fulfillment, gratification, recognition for accomplishments, and satisfaction are being met (Evans, 1997). Job satisfaction is related with both extrinsic such as salary and benefits, promotion, status, a safe environment, and job security and intrinsic rewards such as performance (Lawler, \& Porter, 1967). Some previous research indicate that teachers are satisfied with their teaching work such as professional interest, professional growth but dissatisfied with the performance of their job, such as working conditions, interpersonal relations, and salary (Butt et al., 2005; Crossman \& Harris, 2006). Teachers' job satisfaction has the relationship with their motivation, well-being, and commitment to teaching (Feather \& Rauter, 2004; Vansteenkiste et al., 2007). In addition, teachers' job satisfaction is determined by their teaching efficacy and stress (Caprara, Barbaranelli, Borgogni, \& Steca, 2003; Caprara et al., 2006; Collie et al., 2011), and both stress and teaching efficacy contributed to job satisfaction (Klassen \& Chiu, 2010). The present study identified the job satisfaction measure to examine how teachers' perceptions of job satisfaction, and to determine whether gender was a differentiating factor.

There are variations among teacher perceptions of school environments, teaching efficacy, stress, and job satisfaction (Docker, Fraser \& Fisher, 1989). However, until now no known study has examined whether there are differences between female and male teachers' perceptions of their school-level environment factors, teaching efficacy, teacher stress, and job satisfaction in the setting of Vietnamese high school schools. Therefore, the current study adds to the literature by reporting the results of an investigation to show how teachers' perceptions of school environment factors, teaching efficacy, teacher stress and job satisfaction, and to determine whether gender was a differentiating factor. Two research questions are addressed:

Question 1: What are female and male teachers' perceptions of their school-level environment in terms of dimensions of student support, affiliation, professional interest, mission consensus, innovation, resource adequacy, and principal leadership?

Question 2: Are there gender differences in teachers' perceptions of their school-level environment factors, teaching efficacy, teacher stress, and job satisfaction?

\section{Method}

\subsection{Participants}

A correlational research design was utilized to investigate how teachers' perceptions of school environment factors, teaching efficacy, teacher stress and job satisfaction, and to determine whether gender was a differentiating factor. The sample used consisted of 387 classroom teachers in total ( 213 females [ 55 percent] and 174 males [ 45 percent]) from 7 Vietnamese junior high schools (Grades 10-12). The urban participants were 191 (49 percent) while the suburban participants were 196 (51 percent). The average years of teaching experience for participants was 6.38 (SD $=2.40)$ and the average age for participants was 33.72 years $(\mathrm{SD}=7.75)$. The average age for female participants was 32.73 years $(\mathrm{SD}=7.07)$ while the average age for male participants was 35.37 years $(\mathrm{SD}=8.53)$.

\subsection{Instruments}

\subsubsection{School-level environment}

Thirty six items from School Environment Scale developed by Fisher and Frase (1991) and five items developed by Taylor and Tashakkori (2010) were used to measure teachers' perceptions of school environment factors. Forty nine items of school environment included seven factors. The first factor, called Student Support, contained 6 items (Most students are helpful and cooperative to teachers; There are many disruptive, difficult students in this school; There are many noisy, badly-behaved students; Students get along well with teachers; Most students are well-mannered and respectful to the school staff; Strict discipline is needed to control many of the students). The second factor, called Affiliation, consisted of 5 items (I am ignored by other teachers; I feel that I could rely on my colleagues for assistance if I needed it; My colleagues take notice of my professional views and options; I feel that I have many friends among my colleagues at this school; I feel lonely and left out of things in the staffroom). The third factor, 
called Professional Interest, contained 6 items (Teachers avoid talking with each other about teaching and learning; Staff meetings are dominated by administrative matters rather than teaching and learning issues; Many teachers attend in-service and other professional development courses; Teachers show little interest in what is happening in other schools; Teachers are keen to learn from their colleagues; Teachers show considerable interest in the professional activities of their colleagues). The fourth factor, called Mission Consensus, consisted of 5 items (The school mission statement and its associated goals are well understood by school staff; The organization of this school reflects its goals; Teachers regularly refer to the mission of the school when addressing school issues; My views of the overall mission of this school are very similar to other staff members; The operation of this school is consistent with its goals). The fifth factor, called Innovation, contained 7 items (It is difficult to change anything in this school; Teachers are encouraged to be innovative in this school; There is a great deal of resistance to proposals for curriculum change; Most teachers like the idea of change; New courses or curriculum materials are seldom implemented in the school; There is much experimentation with different teaching approaches; New and different ideas are being tried in this school). The sixth factor, called Resource Adequacy, consisted of 7 items (The school or department library includes an adequate selection of books and periodicals; The supply of equipment and resources is inadequate; Video equipment, tapes and films are readily available and accessible; Adequate copying facilities and services are available to teachers; Tape recorders and cassettes are available when needed; Facilities are inadequate for catering for a variety of classroom activities and learning groups of different sizes; Class sets of important resource books are available when needed). The final factor, called Principal Leadership, contained 5 items (Principal makes plans and carries them out; Principal is interested in innovation; Principal consults staff before making decisions; Goals and priorities for the school are clear; Staff members are recognized for job well done). For each item of this instrument, respondents maked a 1, 2, 3, 4, or 5 for their response, the numbers corresponding to, SD (Strongly Disagree), D (Disagree), U (Undecided), A (Agree), SA (Strongly Agree), respectively. Table 1 describes the means, standard deviations, and alpha coefficient of this scale.

\subsubsection{Teaching efficacy}

Teaching Efficacy Scale developed by Tschannen-Moran and Hoy (2001) was used to measure teaching efficacy of teachers. This scale consisted of 10 items that measure three factors of teaching efficacy. The first factor, called Efficacy for Classroom Management, comprised 3 items (How much can you do to control disruptive behavior in the classroom? How much can you do to calm a student who is disruptive or noisy? How much can you do to get children to follow classroom rules?). The second factor, called Efficacy for Student Engagement, included 3 items (How much can you do to motivate students who show low interest in school work? How much can you do to help your students to believe they can do well in school work? How much can you do to get students to believe they can do well in school work?). The third factor, called Efficacy for Instructional Strategies, consisted of 4 items (To what extent you can craft good questions for your students? To what extent can you use a variety of assessment strategies? To what extent can you provide an alternative explanation or example when students are confused? How much can you assist families in helping their children do well in school?). For each item of this scale, respondents maked a 1, 2, 3, 4, or 5 for their response, the numbers corresponding to, N (Never), HE (Hardly Ever), S (Sometimes), O (Often), VO (Very Often), respectively. Table 1 describes the means, standard deviations, and alpha coefficient of this scale.

\subsubsection{Teacher stress}

Six items from the Teacher Stress Inventory (Boyle et al., 1995) plus an additional item, class size, suggested by Gates (2007) were used to measure two factors of teacher stress. The first factor, called Workload Stress, comprised 4 items (How great a source of stress is having too much work to do? How a great a source of stress is having extra duties/responsibilities because of absent teachers? How great a source of stress is having a large class size? How great a source of stress is being responsible for students' achievement?). The second factor, called Classroom Stress, consisted of 3 items (How great a source of stress is having noisy students? How great a source of stress is maintaining class discipline? How great a source of stress is dealing with students' impolite behavior or rudeness?). For each item of this scale, respondents maked a 1, 2, 3, 4, or 5 for their response, the numbers corresponding to, No Stress, Mild Stress, Moderate Stress, Much Stress, and Extremely Stress, respectively. Table 1 describes the means, standard deviations, and alpha coefficient of this scale.

\subsubsection{Job satisfaction}

Job Satisfaction Scale (Taylor \& Tashakkori, 2010) was used to measure job satisfaction of teachers. This scale consisted of 4 items (Teacher ussually looks forward to each day, Teacher often feels satisfied with job, Teacher is happy just to get through day, Teacher would become a teacher again). For each item of this scale, respondents 
maked a $1=$ Very unsatisfied, $2=$ Dissatisfied, $3=$ Neutral, $4=$ Satisfied, or $5=$ Very satisfied for their response. Table 1 describes the means, standard deviations, and alpha coefficient of this scale.

Table 1. The means, standard deviations (SD), and alpha coefficient $(\alpha)$ of variables

\begin{tabular}{|c|c|c|c|c|c|c|c|}
\hline \multirow[t]{2}{*}{ Variable } & \multicolumn{3}{|c|}{$\begin{array}{c}\text { Female } \\
(\mathrm{n}=213)\end{array}$} & \multicolumn{3}{|c|}{$\begin{array}{c}\text { Male } \\
(\mathrm{n}=174)\end{array}$} & \multirow[b]{2}{*}{ No. Item } \\
\hline & Mean $^{\mathrm{a}}$ & $\mathrm{SD}$ & Alpha $(\alpha)$ & Mean $^{\mathrm{a}}$ & SD & Alpha $(\alpha)$ & \\
\hline \multicolumn{8}{|l|}{ School environment } \\
\hline Student support & 3.75 & .76 & .73 & 3.85 & .78 & .74 & 6 \\
\hline Affiliation & 3.91 & .78 & .74 & 3.99 & .77 & .71 & 5 \\
\hline Professional interest & 4.11 & .82 & .78 & 4.31 & .83 & .80 & 6 \\
\hline Mission consensus & 3.72 & .84 & .76 & 3.82 & .86 & .78 & 5 \\
\hline Innovation & 3.91 & .84 & .83 & 4.11 & .85 & .85 & 7 \\
\hline Resource adequacy & 3.30 & .91 & .82 & 3.44 & .90 & .84 & 7 \\
\hline Principal leadership & 4.13 & .94 & .77 & 4.33 & .90 & .74 & 5 \\
\hline Job satisfaction & 3.32 & 1.00 & .83 & 3.52 & 1.01 & .87 & 4 \\
\hline \multicolumn{8}{|l|}{ Teaching efficacy } \\
\hline Classroom management & 4.02 & .84 & .67 & 4.22 & .83 & .68 & 3 \\
\hline Student engagement & 3.81 & .83 & .69 & 3.94 & .81 & .70 & 3 \\
\hline Instructional strategies & 3.90 & .91 & .73 & 4.11 & .93 & .74 & 4 \\
\hline \multicolumn{8}{|l|}{ Teacher stress } \\
\hline Classroom stress & 4.05 & .74 & .67 & 3.89 & .71 & .68 & 3 \\
\hline Workload stress & 3.90 & .82 & .69 & 3.62 & .83 & .70 & 4 \\
\hline
\end{tabular}

Note: $\mathrm{n}=387$

${ }^{a} 4.20$ - 5.00: Very high, 3.40 - 4.19: High, 2.60 - 3.39: Medium, 1.80 - 2.59: Low, 1.00 - 1.79: Very low

\subsubsection{Procedure}

All of 387 classroom teachers were invited to participate in this study after the permission for access to the study was obtained from the principals of schools and the Department of Education and Training. Participants were clearly explained that they were free to withdraw from the research at any time. The privacy of participants was ensured concerning the information they supplied in the questionnaires. Participants completed one questionnaire for four sections about school-level environment, teaching efficacy, teacher stress, and job satisfaction. The co-researcher personally collected the completed questionnaires from the head teachers in each school. The response rate was almost 100 percent for those teachers.

\subsubsection{Data analysis}

Independent-samples t-tests are conducted to compare the mean scores, on factors of school-level environment, teaching efficacy, teacher stress and job satisfaction, for females and males. For all tests, the significance level was determined with $\mathrm{p}<.05$.

\section{Results}

\subsection{Female and male teachers' perceptions of school-level environment}

The results show that teachers had highly positive perceptions of their school environment in terms of student support, affiliation, professional interest, mission consensus, innovation, resource adequacy, and principal leadership. As indicated in Table 1, all variables had a mean score over 3.70, except resource adequacy. The factor with the highest mean is principal leadership $(\mathrm{M}=4.23, \mathrm{SD}=.98)$, which is followed by professional interest $(\mathrm{M}=4.21, \mathrm{SD}$ $=.85)$, innovation $(\mathrm{M}=4.01, \mathrm{SD}=.89)$, affiliation $(\mathrm{M}=3.95, \mathrm{SD}=.79)$, student support $(\mathrm{M}=3.80, \mathrm{SD}=.77)$, and mission consensus $(\mathrm{M}=3.77, \mathrm{SD}=.86)$. The factor with the lowest mean is resource adequacy $(\mathrm{M}=3.37, \mathrm{SD}=.97)$. An inspection of mean scores in Table 1 indicates that teachers' perceptions of the factors of school-level 
environment in both female and male groups are similar. The actual difference in the two mean scores between the female group and male group on the seven factors was very small, .10 scale point for student support, .08 for affiliation, .20 for professional interest, .10 for mission consensus, and innovation, .14 for resource adequacy, and .20 for principal leadership. Inspection of the results in Table 1 reveals that, on average, teachers' perceptions of their teaching efficacy in both female group and male group are similar. The actual difference in the two mean scores between the female group and male group on the three factors was very small, .20 scale point for classroom management, . 13 for student engagement, .21 for instructional strategies. In addition, in both female group and male group actual difference in the two mean scores on the two factors of stress was very small, .16 for classroom stress, and .28 for workload stress. Also, the actual difference in the two mean scores between the female group and male group on their job satisfaction was very small, .20 scale point.

3.2 Gender differences in teachers' perceptions of their school-level environment factors, teaching efficacy, stress, and job satisfaction

Results (Table 1) indicate that female teachers scored higher than male teachers on both stress while male teachers scored higher than female teachers on school-level environment factors, teaching efficacy and job satisfaction. Results of the t-test analyses (Table 2) show statistically significant differences between females and males on the mean scores of school-level environment factors, teaching efficacy, stress, and job satisfaction. Specifically, there were statistically significant differences between females and males on the student support variable $\left(\mathrm{t}_{(385)}=4.12, \mathrm{p}\right.$ $=.000)$, affiliation $\left(\mathrm{t}_{(385)}=3.76, \mathrm{p}=.012\right)$, professional interest $\left(\mathrm{t}_{(385)}=3.98, \mathrm{p}=.009\right)$, mission consensus $\left(\mathrm{t}_{(385)}=\right.$ $3.43, \mathrm{p}=.015)$, innovation $\left(\mathrm{t}_{(385)}=4.21, \mathrm{p}=.000\right)$, principal leadership $\left(\mathrm{t}_{(385)}=4.29, \mathrm{p}=.000\right)$. However, there was a non-significant difference between females and males on the resource adequacy $\left(\mathrm{t}_{(385)}=1.47, \mathrm{p}=.235\right)$. For teachers' perceptions of their stress, results obtained from t-tests show that there were statistically significant differences between females and males on the classroom stress $\left(\mathrm{t}_{(385)}=3.72, \mathrm{p}=.014\right)$, and workload stress $\left(\mathrm{t}_{(385)}=3.78, \mathrm{p}\right.$ $=.011)$. For teachers' perceptions of their teaching efficacy, there were also statistically significant differences between females and males on the classroom management $\left(\mathrm{t}_{(385)}=4.39, \mathrm{p}=.000\right)$, student engagement $\left(\mathrm{t}_{(385)}=3.96, \mathrm{p}\right.$ $=.007)$, and instructional strategies $\left(\mathrm{t}_{(385)}=4.11, \mathrm{p}=.000\right)$. In addition, results reveal that there was statistically significant difference between females and males on the job satisfaction $\left(\mathrm{t}_{(385)}=3.17, \mathrm{p}=.019\right)$.

Table 2. The results of Independent $\mathrm{t}$-tests between female and male perceptions of variables

\begin{tabular}{|c|c|c|c|c|c|c|}
\hline \multirow[t]{2}{*}{ Variable } & \multicolumn{2}{|c|}{$\begin{array}{c}\text { Female } \\
(\mathrm{n}=213)\end{array}$} & \multicolumn{2}{|c|}{$\begin{array}{c}\text { Male } \\
(\mathrm{n}=174)\end{array}$} & \multirow[b]{2}{*}{$\mathrm{t}$} & \multirow[b]{2}{*}{ p-value } \\
\hline & Mean & SD & Mean & SD & & \\
\hline \multicolumn{7}{|l|}{ School environment } \\
\hline Student support & 3.75 & .76 & 3.85 & .78 & 4.12 & $.000 * *$ \\
\hline Affiliation & 3.91 & .78 & 3.99 & .77 & 3.76 & $.012 *$ \\
\hline Professional interest & 4.11 & .82 & 4.31 & .83 & 3.98 & $.009 *$ \\
\hline Mission consensus & 3.72 & .84 & 3.82 & .86 & 3.43 & $.015^{*}$ \\
\hline Innovation & 3.91 & .84 & 4.11 & .85 & 4.21 & $.000 * *$ \\
\hline Resource adequacy & 3.30 & .91 & 3.44 & .90 & 1.47 & .235 \\
\hline Principal leadership & 4.13 & .94 & 4.33 & .90 & 4.29 & $.000 * *$ \\
\hline Job satisfaction & 3.32 & 1.00 & 3.52 & 1.01 & 3.17 & $.019 *$ \\
\hline \multicolumn{7}{|l|}{ Teaching efficacy } \\
\hline Classroom management & 4.02 & .84 & 4.22 & .83 & 4.39 & $.000 * *$ \\
\hline Student engagement & 3.81 & .83 & 3.94 & .81 & 3.96 & $.007 *$ \\
\hline Instructional strategies & 3.90 & .91 & 4.11 & .93 & 4.11 & $.000 * *$ \\
\hline \multicolumn{7}{|l|}{ Teacher stress } \\
\hline Classroom stress & 4.05 & .74 & 3.89 & .71 & 3.72 & $.014 *$ \\
\hline Workload stress & 3.90 & .82 & 3.62 & .83 & 3.78 & $.011 *$ \\
\hline
\end{tabular}

**Significant difference $(\mathrm{p}<.05) *$ significant difference $(\mathrm{p}<.001)$ 


\section{Discussion}

The purpose of this study is to investigate how teachers' perceptions of school environment factors, teaching efficacy, stress and job satisfaction, and to determine whether gender was a differentiating factor.

\subsection{Teachers' perceptions of their school-level environment}

The findings of the present study indicate that, in general, high school teachers favorably perceived their school-level environment. The research results indicate the validity of the hypothesis that teachers had highly positive perceptions of their school environment in terms of dimensions of student support, affiliation, professional interest, mission consensus, innovation, resource adequacy, and principal leadership. The results of the study show most teachers had good relationships with their students. Students behaved well towards their teachers, and teachers were respected by their students. They cared about students' needs and interests. These high school teachers reported highly that their colleagues had a positive professional commitment, and that teachers cooperated well with their colleagues in the current school. These findings were supported some previous research results of collegiality (Miller et al., 1999; Riehl \& Sipple, 1996) and might explain to some extent these teachers' professional commitment to the teaching occupation. These high school teachers also felt that most of their colleagues had a clear understanding of school goals, and highly valued innovation, as well as positively perceived resource adequacy in their school. In addition, most high school teachers thought positively of their principals. These high school teachers perceived that principals had a positive leadership style in their schools, being interest in innovation, consulting effectively with staff before making decisions and recognizing staff members for doing good job at school. These are consistent with the findings of the previous research studies (Cresswell \& Fisher, 1996; Fisher \& Cresswell, 1998), which found that teachers perceived behavior of their principals as highly cooperative in the working environment. The present study, based on the school-level environment factors as responded by teachers, indicated that this group of high school teachers enjoyed their profession (Marlow, Inman, \& Betancourt-Smith, 1995). These are consistent with results of previous studies that teachers' highly positive perceptions of their school environment are associated with teacher commitment, and school effectiveness (Latham, 1998; Miller et al., 1999; Shann, 1998).

4.2 Gender differences in teachers' perceptions of their school-level environment factors, teaching efficacy, teacher stress, and job satisfaction

Results show that statistically significant differences were found between females and males on the mean scores of school-level environment factors, teaching efficacy, stress, and job satisfaction. The findings indicate that male teachers with positively high perceptions of school-level environment in terms of professional interest, affiliation, mission consensus, student support, resource adequacy, and principal leadership had greater job satisfaction, whereas female teachers with positively low perceptions of school-level environment had lower job satisfaction. The findings highlight that factors of school environment play an important role for high school teachers' job satisfaction. This result is consistent with the findings of previous research studies (Butt et al., 2005; Collie et al., 2012; Cresswell \& Fisher, 1996; Fisher \& Fraser, 1990; Taylor \& Tashakkori, 2010; Taylor \& Tashakkori, 1995), which found that school environment factors affect teachers' job satisfaction. Therefore, all of these school-level environment factors should be promoted to increase teachers' job satisfaction. Administrators and policy makers need to review their school environment profiles based on the results of this study to identify which aspects of school-level environment need to be change and improved.

In addition, the results show that male teachers who perceived better school environment factors reported greater classroom management (ability to manage the classroom effectively), student engagement (ability to engage students in learning effectively), and usage of instructional strategies (ability to use teaching strategies effectively). The findings indicate the importance role of school-level environment factors for teachers' teaching efficacy in the working context. This means that teachers who had greater positive perceptions of school-level environment perceived greater management ability for classrooms, better engagement ability for student learning and greater usage of instructional strategies. This result is consistent with the findings of previous research studies (Butt et al., 2005; Caprara et al., 2006; Caprara et al., 2003; Collie et al., 2011; Collie et al., 2012; Fisher \& Fraser, 1990), which indicated that factors of school-level environment impacted teachers' teaching efficacy at work. The results show that in order to improve the effectiveness of school-level environment, educators and administrators should consider effects of teachers' perceptions of school environment factors on their teaching efficacy are fundamental to high school teachers' experience.

Furthermore, male teachers who had greater professional interest, affiliation, mission consensus, student support, resource adequacy, and principal leadership reported lower classroom stress and lower workload stress. In contrast, female teachers with lower level of professional interest, affiliation, mission consensus, student support, resource 
adequacy, and principal leadership had greater classroom stress and greater workload stress. This result is consistent with the findings of previous research studies (Collie et al., 2012; Fisher \& Fraser, 1990) that show that dimensions of school environment influence teacher stress. The finding indicates male teachers with greater teaching efficacy had greater job satisfaction, whereas female teachers with greater stress had lower job satisfaction and lower teaching efficacy. The findings are consistent with previous research (Collie et al., 2012; Caprara et al., 2006; Klassen \& Chiu, 2010). This shows that educators should, therefore, provide teachers with appropriate and effective pre-service and in-service professional development in managing classroom, engaging student learning and implementing effective teaching strategies to help teachers form their confidence.

The results indicate that female teachers with greater student behavior stress and workload stress had lower teaching efficacy. In other words, high school teachers who experience more student behavior stress and workload stress reported less success in managing students' behavior, engaging students in learning, or applying effective instructional strategies in the classrooms. The results of this study validate the findings of previous research (Collie et al., 2012; Klassen \& Chiu, 2010; Taylor \& Tashakkori, 2010), which indicate there was a negatively significant relationship between teachers' teaching efficacy and their stress. The findings provide educators with significant information to integrate different skills into teacher education programs to help teachers work effectively with their students and colleagues so that they have the lowest experience of student behavior stress and workload stress. The results indicated that teachers' school environment had positively significant influences on the three outcome variables - teaching efficacy, stress and job satisfaction. This finding shows that teachers closely associated with their school environment. Apparently, teachers are influenced directly by their perceptions of school environment factors, and this affects their teaching efficacy, stress, and job satisfaction.

\section{Conclusion}

The present study indicates that, in general, high school teachers favorably perceived their school-level environment. Results also show statistically significant differences between females and males on the mean scores of school-level environment factors, teaching efficacy, stress, and job satisfaction. The present study identifies gender as a variable differentiating teachers' perceptions of school environment, teaching efficacy, teacher stress and job satisfaction. Female teachers with greater stress had lower perceptions of school-level environment factors, lower teaching efficacy and lower job satisfaction, whereas male teachers with less stress had higher perceptions of school-level environment factors, higher teaching efficacy and higher job satisfaction. Results provide a strong confirmation of the importance of teachers' perceptions of school-level environment for their work experiences. The present study supports gender had effects on perceptions of school-level environment factors which shape their experiences at work. In other words, teachers' perceptions of school-level environment are significantly related to their experiences of teaching efficacy, stress, and job satisfaction. The study also provides clear evidence for previous research on the possible inter-correlations among the four factors- school-level environment, teaching efficacy, stress, and job satisfaction (Klassen \& Chiu, 2010; Collie et al., 2012). Educators and administrators may, based on the findings of this study, recognize which facets of school-level environment should be changed and improved, and then find effective solutions for improvement. These findings would be useful in shaping school policy regarding school reconstructing in the setting of Vietnamese high schools. From the findings of this study, a positive school environment results in an increase in teachers' teaching efficacy, and job satisfaction and a decrease in stress included student behavior stress and workload stress.

\section{References}

Bandura, A. (1977). Self-efficacy: Towards a unifying theory of behavioural change. Psychological Review, 84(2), 191-215. http://dx.doi.org/10.1037/0033-295X.84.2.191

Boyle, G. J., Borg, M. G., Falzon, J. M., \& Baglioni Jr., A. J. (1995). A structural model of the dimensions of teacher $\begin{array}{lllll}\text { stress. British Journal of Educational } & \text { Psychology, }\end{array}$ http://dx.doi.org/10.1111/j.2044-8279.1995.tb01130.x

Butt, G., Lance, A., Fielding, A., Gunter, H., Rayner, S., \& Thomas, H. (2005). Teacher job satisfaction: Lessons from the TSW pathfinder project. School Leadership and Management, 25(5), 455-471. http://dx.doi.org/10.1080/13634230500340807

Caprara, G. V., Barbaranelli, C., Borgogni, L., \& Steca, P. (2003). Efficacy Beliefs as Determinants of Teachers' Job Satisfaction. Journal of Educational Psychology, 95(4), 821-832. http://dx.doi.org/10.1037/0022-0663.95.4.821 
Caprara, G. V., Barbaranelli, C., Steca, P., \& Malone, P. S. (2006). Teachers' self-efficacy beliefs as determinants of job satisfaction and students' academic achievement: A study at the school level. Journal of School Psychology, 44(6), 473-490. http://dx.doi.org/10.1016/j.jsp.2006.09.001

Cohen, J., McCabe, L., Michelli, N. M., \& Pickeral, T. (2009). School climate: Research, policy, practice, and teacher education. Teachers College Record, 111(1), 180-213.

Collie, R. J., Shapka, J. D., \& Perry, N. E. (2011). Predicting teacher commitment: The impact of school climate and social-emotional learning. Psychology in the Schools, 48(10), 1034-1048. http://dx.doi.org/10.1002/pits.20611

Collie, R. J., Shapka, J. D., \& Perry, N. E. (2012). School climate and social-emotional learning: predicting teacher stress, job satisfaction, and teaching efficacy. Journal of Educational Psychology, 104(4), 1189-1204. http://dx.doi.org/10.1037/a0029356

Cresswell, J., \& Fisher, D. (1996, April 8-12). Relationship between principal's interpersonal behavior with teachers and the school environment. Paper presented at the annual meeting of the American Educational Research Association, New York, America. Retrieved from http://files.eric.ed.gov/fulltext/ED395392.pdf.

Crossman, A., \& Harris, P. (2006). Job satisfaction of secondary school teachers. Educational Management Administration and Leadership, 34(1), 29-46. http://dx.doi.org/10.1177/1741143206059538

Chaplain, R. P. (2008). Stress and psychological distress among trainee secondary teachers in England. Educational Psychology, 28(2), 195-209. http://dx.doi.org/10.1080/01443410701491858

Chen, W. (2007). The structure of secondary school teacher job satisfaction and its relationship with attrition and work enthusiasm. Chinese Education and Society, 40(5), http://dx.doi.org/10.2753/CED1061-1932400503

De Nobile, J. J., \& McCormick, J. (2005, Nov. 27- Dec. 1). Job satisfaction and occupational stress in catholic primary schools. Paper presented at the Annual Conference of the Australian Association for Research in Education, Sydney, Australia. Retrieved from http://www.aare.edu.au/data/publications/2005/den05203.pdf.

Evans, L. (1997). Understanding teacher morale and job satisfaction. Teaching and Teacher Education, 13(8), 831-845. http://dx.doi.org/10.1016/S0742-051X(97)00027-9

Feather, N. T., \& Rauter, K. A. (2004). Organizational citizenship behaviors in relation to job status, job insecurity, organizational commitment and identification, job satisfaction, and work values. Journal of Occupational and Organizational Psychology, 77(1), 81-94. http://dx.doi.org/10.1348/096317904322915928

Fisher, D. L., \& Cresswell, J. (1998). Actual and ideal principal interpersonal behavior. Learning Environment Research, 1(2), 231-247. http://dx.doi.org/10.1023/A:1009914102379

Fisher, D. L., \& Fraser, B. J. (1990). Validity and use of the school-level environment questionnaire. Paper presented at the Annual Meeting of the American Educational Research Association, Boston, MA. Retrieved from http://files.eric.ed.gov/fulltext/ED318757.pdf.

Freiberg, H. J. (1999). Introduction. In H. J. Freiberg (Ed.), School climate: Measuring, improving, and sustaining healthy learning environments (pp.1-11). Philadelphia, PA: Falmer Press.

Gates, G. S. (Ed.). (2007). Emerging thought and research on student, teacher, and administrator stress and coping. Charlotte, NC: Information Age Publishing.

Geving, A. M. (2007). Identifying the types of student and teacher behaviours associated with teacher stress. Teaching and Teacher Education, 23(5), 624-640. http://dx.doi.org/10.1016/j.tate.2007.02.006

Grayson, J. L., \& Alvarez, H. K. (2008). School climate factors relating to teacher burnout: A mediator model. Teaching and Teacher Education, 24(5), 1349-1363. http://dx.doi.org/10.1016/j.tate.2007.06.005

Greenglass, E. R., \& Burke, R. J. (2003). Teacher stress. In M. F. Dollard, T. H. Winefield, \& H. R. Winefield (Eds.), Occupational stress in the service professions (pp. 213-236). New York, NY: Taylor and Francis. http://dx.doi.org/10.1201/9780203422809.ch8

Hoy, A. W., \& Spero, R. B. (2005). Changes in teacher efficacy during the early years of teaching: A comparison of four measures. Teaching and Teacher Education, 21(4), 343-356. http://dx.doi.org/10.1016/j.tate.2005.01.007

Hoy, W. K., \& Woolfolk, A. E. (1993). Teachers' sense of efficacy and the organizational health of schools. Elementary School Journal, 93(4), 355-372. http://dx.doi.org/10.1086/461729 
Jepson, E., \& Forrest, S. (2006). Individual contributory factors in teacher stress: The role of achievement striving and occupational commitment. British Journal of Educational Psychology, 76(1), 183-197. http://dx.doi.org/10.1348/000709905X37299

Klassen, R. M., \& Chiu, M. M. (2010). Effects on teachers' self-efficacy and job satisfaction: Teacher gender, years of experience, and job stress. Journal of Educational Psychology, 102(3), 741-756. http://dx.doi.org/10.1037/a0019237

Kokkinos, C. M. (2007). Job stressors, personality, and burnout in primary school teachers. British Journal of Educational Psychology, 77(1), 229-243. http://dx.doi.org/10.1348/000709905X90344

Kyriacou, C. (2001). Teacher stress: Directions for future research. Educational Review, 53(1), 27-35. http://dx.doi.org/10.1080/00131910120033628

Latham, A. S. (1998). Teacher satisfaction. Educational Leadership, 55(5), 82-83.

Lawler, E. E., \& Porter, L. W. (1967). The effects of performance on job satisfaction. Industrial Relations: A Journal of Economy and Society, 7(1), 20-28. http://dx.doi.org/10.1111/j.1468-232x.1967.tb01060.x

Loukas, A., \& Murphy, J. L. (2007). Middle school student perceptions of school climate: Examining protective functions on subsequent adjustment problems. Journal of School Psychology, 45(3), 293-309. http://dx.doi.org/10.1016/j.jsp.2006.10.001

Marlow, L., Inman, D., \& Betancourt-Smith, M. (1995). Profiling the likely school leaver: An encouraging look at schools in a nine-state sample. Education, 115(3), 435-440.

McCarthy, C. J., Lambert, R. G., O’Donnell, M., \& Melendres, L. T. (2009). The relation of elementary teachers' experience, stress, and coping resources to burnout symptoms. Elementary School Journal, 109(3), 282-300. http://dx.doi.org/10.1086/592308

McLaughlin, M. W. (1993). What's matters most in teacher's workplace context? In J. W. Little \& M.W. McLaughlin (Eds.), Teachers' work: Individuals, colleagues, and context (pp.79-103). New York: Teacher College Press.

Miller, M. D., Brownell, M. T., \& Smith, S. W. (1999). Factors that predict teachers staying in, leaving, or transferring from the special education classroom. Exceptional Children, 65(2), 201-218.

Perry, A.C. (1908). The management of a city school. New York, NY: Macmillan.

Riehl, C., \& Sipple, J. W. (1996). Making the most of time and talent: Secondary school organizational climates, teaching task environment, and teacher commitment. American Educational Research Journal, 33(4), 873-901. http://dx.doi.org/10.3102/00028312033004873

Ross, J. A., Hogaboam-Gray, A., \& Hannay, L. (2001). Effects of teacher efficacy on computer skills and computer cognitions of Canadian students in Grades K-3. Elementary School Journal, 102(2), 141-156. http://dx.doi.org/10.1086/499697

Schaufeli, W. B., \& Bakker, A. B. (2004). Job demands, job resources, and their relationship with burnout and engagement: A multi-sample study. Journal of Organizational Behaviour, 25(3), 293-315. http://dx.doi.org/10.1002/job.248

Schwarzer, R., \& Hallum, S. (2008). Perceived teacher self-efficacy as a predictor of job stress and burnout: Mediation analyses. Applied Psychology, 57, 152-171. http://dx.doi.org/10.1111/j.1464-0597.2008.00359.x

Selye, H. (1974). Stress without distress. Philadelphia, PA: Lippincott.

Shann, M. H. (1998). Professional commitment and satisfaction among teachers in urban middle schools. Journal of Educational Research, 92(2), 67-73. http://dx.doi.org/10.1080/00220679809597578

Skaalvik, E. M., \& Skaalvik, S. (2009). Does school context matter? Relations with teacher burnout and job satisfaction. Teaching and Teacher Education, 25(3), 518-524. http://dx.doi.org/10.1016/j.tate.2008.12.006

Tarter, C.J, Hoy, W.K., \& Kottkamp, R.B. (1990). School climate and organizational commitment. Journal of Research and Development in Education, 23, 236-242.

Taylor, D. L., \& Tashakkori, A. (1995). Decision participation and school climate as predictors of job satisfaction and teacher's sense of efficacy. Journal of Experimental Education, 63(3), 217-230. http://dx.doi.org/10.1080/00220973.1995.9943810 
Tschannen-Moran, M., \& Hoy, A. W. (2001). Teacher efficacy: Capturing an elusive construct. Teaching and Teacher Education, 17(7), 783-805. http://dx.doi.org/10.1016/S0742-051X(01)00036-1

Tschannen-Moran, M., \& Hoy, A. W. (2007). The differential antecedents of self-efficacy beliefs of novice and experienced teachers. Teaching and Teacher Education, 23(6) 944-956. http://dx.doi.org/10.1016/j.tate.2006.05.003

Tsouloupas, C. N., Carson, R. L., Matthews, R., Grawitch, M. J., \& Barber, L. K. (2010). Exploring the association between teachers' perceived student misbehaviour and emotional exhaustion: The importance of teacher efficacy beliefs and emotion regulation. Educational Psychology, 30(2), 173-189. http://dx.doi.org/10.1080/01443410903494460

Thomas, N., Clark, V., \& Lavery, J. (2003). Self-reported work and family stress of female primary teachers. Australian Journal of Education, 47(1), 73-87. http://dx.doi.org/10.1177/000494410304700106

Vansteenkiste, M., Neyrinck, B., Niemiec, C. P., Soenens, B., De Witte, H., \& Van den Broeck, A. (2007). On the relations among work value orientations, psychological need satisfaction and job outcomes: A self-determination theory approach. Journal of Occupational \& Organizational Psychology, 80(2), 251-277. http://dx.doi.org/10.1348/096317906X111024

Weiss, E. M. (1999). Perceived workplace conditions and first-year teachers' morale, career choice commitment, and planned retention: A secondary analysis. Teaching and Teacher Education, 15(8), 861-879. http://dx.doi.org/10.1016/S0742-051X(99)00040-2

Wilson, V. (2002). Feeling the strain: An overview of the literature on teachers' stress (SCRE Research Report No 109). Glasgow, Scotland: Scottish Council for Research in Education. Retrieved from http://217.35.77.12/research/scotland/education/109.pdf. 